\title{
Site-selection model for optimal transplantation of eelgrass Zostera marina in the northeastern US
}

\author{
F. T. Short ${ }^{1, *}$, R. C. Davis $^{2}$, B. S. Kopp ${ }^{1}$, C. A. Short $^{1}$, D. M. Burdick ${ }^{1}$ \\ ${ }^{1}$ Jackson Estuarine Laboratory, University of New Hampshire, 85 Adams Point Road, Durham, New Hampshire 03824, USA \\ ${ }^{2}$ Rummel, Klepper \& Kahl, Consulting Engineers, 81 Mosher Street, Baltimore, Maryland 21217, USA
}

\begin{abstract}
A site-selection model for eelgrass Zostera marina L. ecosystem restoration was developed in the northeastern US to select optimal areas for transplanting eelgrass. The site-selection model synthesizes available historic and literature-based information, reference data, and simple field measurements to identify and prioritize locations for large-scale eelgrass transplantation. Model development was based on the physical and biological characteristics associated with the most successful transplant sites in a mitigation project for the New Hampshire Port Authority. The site-selection process is divided into 3 phases: (1) the first phase uses available environmental information to formulate a preliminary transplant suitability index (PTSI) for pre-screening and eliminating unsuitable sites; (2) the second phase involves field measurements of light availability and bioturbation as well as survival and growth of test transplants at priority sites identified by the PTSI; (3) a transplant suitability index (TSI) score is calculated for each site based on the PTSI and the results of field assessments. The TSI is a multiplicative index that eliminates sites which receive ratings of zero and gives high scores to those sites with the greatest potential for successful transplantation. We applied the TSI post hoc to the New Hampshire Port Project's eelgrass transplant sites, and subsequently the site-selection model was used in an eelgrass restoration project in New Bedford Harbor, Massachusetts. After 2 yr of transplanting, the New Bedford Harbor effort has resulted in success at $62 \%$ of the sites planted using the site-selection model.
\end{abstract}

KEY WORDS: Seagrass · Eelgrass · Zostera marina · Restoration · Transplanting · Site-selection Resale or republication not permitted without written consent of the publisher

\section{INTRODUCTION}

Eelgrass Zostera marina L. meadows provide a wide array of ecological functions that are important in maintaining healthy estuarine and coastal ecosystems. Eelgrass meadows form a basis of primary production that supports ecologically and economically important species (Orth et al. 1984, Thayer et al. 1984, Heck et al. 1995). Over the last decade, Atlantic eelgrass populations have declined due to pollution associated with increased human populations (Kemp et al. 1983, Valiela et al. 1992, Short \& Burdick 1996) and episodic occurrences of the wasting disease (Short et al. 1986, den Hartog 1994), as well as other human-induced and

*E-mail: fred.short@unh.edu natural disturbances (Short \& Wyllie-Echeverria 1996). Because of the critical role eelgrass habitat plays in estuarine and coastal systems, efforts are under way to prevent further losses and, recently, to restore eelgrass populations to historic distributions (Stevenson et al. 1993). Once eelgrass cover is lost, physical and biological site characteristics may change (Rasmussen 1977, Christiansen et al. 1981, Duarte 1995, Olesen 1996). Such changes can prevent natural recolonization of historic eelgrass sites even when water quality is adequate. Transplanting can establish eelgrass habitat decades before natural processes might permit recolonization. Eelgrass transplantation has been used to restore habitat as well as to mitigate eelgrass loss or damage on the Atlantic coast of the US (Davis \& Short 1997, Fonseca et al. 1998). 
Seagrass transplant success varies considerably (Thom 1990, Fonseca 1992, Davis \& Short 1997, Fonseca et al. 1998). Of the possible factors that can directly influence the survival of transplanted eelgrass, poor site-selection (Harrison 1990, Fonseca 1992) has been identified as the major limitation: often sites with insufficient light associated with poor water quality (Zimmerman et al. 1991, 1995, Reid et al. 1993, Stevenson et al. 1993) are selected. Excess inorganic nitrogen can contribute to reduced light conditions or smothering by macroalgae (Costa et al. 1992, Short et al. 1995). Additionally, bioturbation has been shown to be a factor that can greatly reduce the survival and expansion of both naturally occurring (Suchanek 1983, Philippart 1994) and transplanted (Harrison 1987, Fonseca et al. 1994, 1996, Philippart 1994, Molenaar \& Meinesz 1995, Davis et al. 1998) seagrass.

A site-selection model would provide scientists and practitioners with a tool for increasing the success of costly transplant efforts. Much of the eelgrass restoration work to date has relied upon the 'best professional judgement' of those with knowledge of the habitat and its requirements. However, as eelgrass transplantation becomes more widely used, the need to optimize the decision-making process for site-selection is clear. Here, we focus on eelgrass habitats in the northeastern US, building on the work of others (Batiuk et al. 1992, Fonseca et al. 1998) and incorporating our transplant experience to develop a quantitative site-selection model based on scientific criteria.

Model development was based on monitoring of eelgrass transplant sites in the Great Bay Estuary (Davis \& Short 1997) for the New Hampshire Port Authority Mitigation Project (Port Project). The physical and biological characteristics of the most successful transplanting sites (Short et al. 2000) were compiled to formulate the model's parameters (Davis 1999). Locating and prioritizing areas of potential eelgrass habitat is the essence of transplant site-selection. Potential eelgrass habitat consists of those areas that are currently unvegetated but that have appropriate conditions to support eelgrass. The transplant suitability index (TSI) is designed for the restoration of eelgrass in the northeastern US, in the middle of its latitudinal range; thus its application to other locations and seagrass species will require adjustment. However, the logical development and framework of the model are applicable to other locations and even other habitats.

\section{MATERIALS AND METHODS}

Once the goals and geographic boundaries of an eelgrass transplant project are established, site-selection is the next critical step. Our site-selection model has 3 phases: Phase I identifies potential eelgrass habitat by taking advantage of available knowledge, eliminates some sites from further costly consideration before field testing, and yields one of the scores that contribute to the calculation of the TSI. Phase II involves field assessment of the best-scoring areas identified in Phase I. Phase III is the final calculation of the TSI, based on results from Phases I and II.

Phase I: identification of potential eelgrass habitat and PTSI rating. Phase I involves review of available information to select and prioritize potential transplant sites from within the geographic boundaries of the project. In Phase I, information on characteristics of vegetated and unvegetated areas, along with sediment type, wave exposure, depth, and water quality are compiled to identify possible transplanting areas, essentially sites of 'potential eelgrass habitat'. These characteristics contribute to the 'preliminary transplant suitability index' (PTSI), which is used as the first level of screening in site-selection (Table 1). Information for the PTSI may well be available for many locations in published and unpublished literature; however, if not available, basic field measurements of the various PTSI parameters will have to be done. After the completion of Phase I, a base map is constructed showing areas of existing eelgrass habitat as well as those areas determined to be potential eelgrass habitat and therefore suitable for further investigation as eelgrass transplant sites. Each of the parameters in Phase I receives a rating (Table 1), and the PTSI score is calculated as the product of these ratings. As a multiplicative index, a zero rating for any parameter drives the PTSI to zero, eliminating the site from further consideration. Sites with higher scores have greater likelihood of being successful transplant sites and are ranked for further TSI evaluation.

Historical eelgrass distribution, the first parameter of Phase I (Table 1), is recommended by Fonseca et al. (1998) as an important consideration in selecting transplant sites. Eelgrass transplantation does not need to be limited to sites of historical eelgrass distribution. Doing so may result in greater transplant success than in previously unvegetated sites, although the historical cause of eelgrass loss could limit eelgrass reestablishment. Previously vegetated sites receive a PTSI rating of 2 and previously unvegetated sites (or those with no record) receive a rating of 1 (Table 1). Current eelgrass distribution is important knowledge relative to transplanting activities, because restoration should not be considered at sites where eelgrass already exists. Thus, currently vegetated sites are rated 0 , while unvegetated sites are rated 1. If sites historically had eelgrass, but lack it currently, the remainder of the PTSI will point out some of the parameters that may have been responsible for eelgrass loss. If a site has no 
record of eelgrass, either currently or historically, then application of the remainder of the PTSI will provide an assessment of the site as potential eelgrass habitat.

The distance of a possible transplant site from natural eelgrass beds is calculated using current eelgrass distribution data. This parameter is included to insure that transplanting is taking place outside an area that could be naturally revegetated by seed. If a site is less than $100 \mathrm{~m}$ from a natural eelgrass bed, it is considered within the range of natural revegetation, based on Orth et al. (1994), and receives a rating of 0 . If a site is over $100 \mathrm{~m}$ from a natural eelgrass bed, it is rated 1 .

Sediment grain size has been suggested as an important variable influencing eelgrass growth (Kenworthy \& Fonseca 1977, Short 1987, 1993). For the purpose of site-selection, only a general rule can be derived from the literature: that is, if a site is rock or cobble it is rated 0 , if the site is $>70 \%$ silt/clay it is rated 1 , and if it is cobble-free with $<70 \%$ silt-clay, it is rated 2 , indicating the preferred sediment condition.

Wave exposure is included as a parameter in the PTSI because it has been demonstrated that wave energy can break leaves and uproot plants (Kopp 1999), which is clearly detrimental to eelgrass transplants (Fonseca et al. 1998). Several studies have looked at methods for calculating the effect of wave exposure on eelgrass, based on the fetch and wind pat- terns experienced at any particular site (Kopp et al. 1994, Murphey \& Fonseca 1995). The relative exposure index (Keddy 1982, Murphey \& Fonseca 1995) is a method of predicting gradients in wave exposure based upon wind velocity, directional percent frequency of the wind, and the distance over the water that waves can build (fetch). Unfortunately, an absolute wave exposure limit for eelgrass has not been established, and the available methods for predicting exposure may be insufficient as they do not account for bathymetry (Koch 1999). For Phase I, we established the wave exposure parameter based on calculation of the relative wave exposure at local eelgrass reference sites using the method of Murphey \& Fonseca (1995). If the wave exposure at a possible transplant site is greater than the mean $+2 \mathrm{SD}$ at the reference sites, the site is rated 0 and eliminated, because of possible excess wave exposure. Otherwise, the site is rated 1.

Water depth is a critical factor limiting the distribution of eelgrass (Dennison 1987, Short \& Neckles 1999). In the intertidal zone, the depth to which eelgrass can grow is influenced by desiccation and exposure, and in deep water by the amount of light reaching the bottom, which in turn is determined by water quality and clarity. The depths to which eelgrass will grow in estuarine and coastal environments vary widely between locations (Duarte 1991). For this reason, we again chose to

Table 1. Data used during Phase I in the preliminary transplant suitability index (PTSI) for identification of potential eelgrass habitat. Maximum possible PTSI score $=16$. GIS: Geographic Information System. DIN: dissolved inorganic nitrogen; TON: total organic nitrogen

\begin{tabular}{|c|c|c|}
\hline Parameter (source) & PTSI rating & Reference \\
\hline $\begin{array}{l}\text { Historical eelgrass distribution } \\
\text { (distribution maps) }\end{array}$ & $\begin{array}{l}1 \text { for previously unvegetated } \\
2 \text { for previously vegetated }\end{array}$ & Fonseca et al. (1998) \\
\hline $\begin{array}{l}\text { Current eelgrass distribution } \\
\text { (distribution maps) }\end{array}$ & $\begin{array}{l}0 \text { for currently vegetated } \\
1 \text { for currently unvegetated }\end{array}$ & \\
\hline $\begin{array}{l}\text { Proximity to natural eelgrass bed } \\
\text { (map or GIS calculation) }\end{array}$ & $\begin{array}{l}0 \text { for }<100 \mathrm{~m} \\
1 \text { for } \geq 100 \mathrm{~m}\end{array}$ & Orth et al. (1994) \\
\hline $\begin{array}{l}\text { Sediment } \\
\text { (distribution map) }\end{array}$ & $\begin{array}{l}0 \text { for rock or cobble } \\
1 \text { for }>70 \% \text { silt/clay } \\
2 \text { for cobble free with }<70 \% \text { silt/clay }\end{array}$ & $\begin{array}{l}\text { Kenworthy \& Fonseca (1977) } \\
\text { Short }(1987,1993)\end{array}$ \\
\hline $\begin{array}{l}\text { Wave exposure } \\
\text { (map or GIS calculation) }\end{array}$ & $\begin{array}{l}0 \text { for }>\text { mean }+2 \mathrm{SD}^{\mathrm{a}} \\
1 \text { for } \leq \text { mean }+2 \mathrm{SD}^{\mathrm{a}}\end{array}$ & $\begin{array}{l}\text { Kopp et al. (1994) } \\
\text { Murphey \& Fonseca (1995) } \\
\text { Fonseca et al. (1998) }\end{array}$ \\
\hline $\begin{array}{l}\text { Water depth } \\
\text { (NOAA navigation charts) }\end{array}$ & $\begin{array}{l}0 \text { for too shallow or too deep } \\
1 \text { for shallow edge of reference bed } \\
2 \text { for average of reference bed } \\
1 \text { for deep edge of reference bed }\end{array}$ & Short (1993) \\
\hline $\begin{array}{l}\text { Water quality } \\
\text { (based on available phytoplankton } \\
\text { pigments, DIN, TON, Secchi depth, } \\
\text { eutrophication index, or habitat } \\
\text { requirements) }\end{array}$ & $\begin{array}{l}0 \text { for poor } \\
1 \text { for fair } \\
2 \text { for good }\end{array}$ & $\begin{array}{l}\text { Batiuk et al. (1992) } \\
\text { Dennison et al. (1993) } \\
\text { Costa et al. (1996) }\end{array}$ \\
\hline
\end{tabular}


establish the depth parameter in comparison to local reference eelgrass beds (Short 1993); units for water depth are based on available information, and are not critical as long as they are consistent between measurements and ratings. A rating of 0 is assigned to sites that are too shallow or too deep, a rating of 1 for depths similar to the shallow or deep edges of local reference eelgrass beds, and a rating of 2 for areas with depths near the average depth of local reference beds.

Like water depth, water quality is a location-specific parameter, with various types of data suitable to rate water quality for the PTSI, depending on what is available. The water quality parameter can be established from information on phytoplankton abundance, TSS, Secchi disk depth, DIN, TON, requirements of submerged aquatic vegetation total suspended solids (Batiuk et al. 1992), or composite water-quality indices (Costa et al. 1996). In general, the water-quality parameter is given a rating of 0 if water quality is poor, a rating of 1 if water quality is fair, and a rating of 2 if water quality is good. These highly generalized ratings can be translated into specific parameters as seen in the 2 applications (see 'Results and discussion'). Should any of the data layers or information sources listed in Table 1 be lacking, some field work may be needed or that parameter may be dropped from the PTSI but with a resulting loss in predictive power.

The PTSI score is calculated by multiplying the ratings of each parameter in Table 1 ; possible PTSI scores are $0,1,2,4,8$, and 16 . Sites with a PTSI of 0 or 1 receive no further consideration for transplanting. Sites with PTSI scores of 2 or greater are ranked; higher numbers indicate better likelihood of transplant success, i.e. better potential eelgrass habitat. Selection of sites for further evaluation in Phase II is based on PTSI score and the number and area of transplant sites ultimately required; only these areas are considered in Phases II and III of the TSI process. The end product of Phase I is a table or map ranking all areas of potential eelgrass habitat within the geographic boundaries of the project (see 'Results and discussion').

Beyond the identification of potential eelgrass habitat, additional factors may also influence the success of eelgrass transplantation and need to be considered, but they are not incorporated into the PTSI. Areas that support shellfish beds and areas of high boat traffic should be identified and excluded as possible transplant sites. Shellfishing and boating are recognized problems for the survival of natural eelgrass beds, and therefore pose a threat to eelgrass transplant efforts. Nutrient stress from excess nutrient loading to the estuary at or near potential transplant sites may impact eelgrass survival (Short \& Burdick 1996), but it is not expressed within the assessments of water quality in Table 1 as relevant data are rarely available.
Phase II: field assessments and test-transplanting. Phase II includes obtaining site-specific light data, field assessment of bioturbation activity, and monitoring the survival, growth and nitrogen status of eelgrass testtransplants. An adequate number of potential eelgrass habitat sites, determined by high PTSI scores in Phase I, are evaluated to insure sufficient acreage of desirable sites for transplanting. Assessment of light and bioturbation and the effort of test-transplants are not inexpensive, but ultimately save costs by focusing effort and money on full-scale transplanting at the sites with the highest likelihood of success (Fonseca et al. 1998).

Light is a critical factor in the survival and growth of eelgrass populations (Dennison 1987, Short et al. 1995). Reduced light conditions have been implicated in limiting eelgrass metabolic activity, resulting in plant death (Dennison et al. 1993, Zimmerman et al. 1995). Seagrasses require a minimum of $20 \%$ of surface light to survive (Duarte 1991, Dennison et al. 1993), but greater light levels increase seagrass growth (Short et al. 1995). Light can be assessed using many different methods, including Secchi disk determinations (Dennison et al. 1993), measurement of light extinction (Dennison 1987), and long-term underwater monitoring (Short et al. 1993, Lee \& Dunton 1996). To determine the percent surface irradiance reaching the plants, surface light must be measured for comparison with irradiance at the bottom. Alternatively, the amount of light necessary for eelgrass growth can be determined by comparison with light levels at local, naturally occurring, eelgrass beds.

We recorded bottom light levels (modified ENDECO 174 SSM with a LiCor $4 \pi$ sensor added: Short et al. 1993) for 3 to $4 \mathrm{~d}$ at areas with high PTSI scores and at local reference eelgrass beds. One light sensor was placed in a naturally occurring eelgrass bed (in an opening such that it would not be shaded by the plants), and another was moved at 3 to $4 \mathrm{~d}$ intervals among those sites with high PTSI scores; the sensors were cleaned every 3 to $4 \mathrm{~d}$. This approach is a quick, reliable method of determining the amount of light reaching the bottom at possible transplant sites relative to a local, natural eelgrass bed. The existence of eelgrass in the naturally occurring bed demonstrates that sufficient light reaches the bottom to support the plants. If light levels (measured at the same time) exceed those at the naturally occurring beds, then transplants have a greater chance to do well. Of course short-term measurements of light may not always be representative, but we have used this method successfully as an indicator of the longer-term light regime. Generally, deployment of light sensors should occur during the most active growing season.

Bioturbation has been documented as an important factor affecting both natural and transplanted eelgrass 
Table 2. Bioturbating organisms known to damage eelgrass transplants or identified as a threat to eelgrass survival

\begin{tabular}{|lllll|}
\hline Bioturbators & \multicolumn{1}{c}{ Species } & \multicolumn{2}{c}{ Impact } & \multicolumn{1}{c|}{ Location } \\
\hline Cownose ray & Rhinoptera bonasus & Excavation & Chesapeake Bay, USA & Orth (1975) \\
Horseshoe crabs & Limulus polyphemus & Excavation & New Hampshire, USA & F. T. Short (pers. obs.) \\
Green crabs & Carcinus maenas & Clipping at $\geq 4.0$ crabs m ${ }^{-2}$ & New Hampshire, USA & Davis et al. (1998) \\
Spider crabs & Libinia spp. & Clipping & Massachusetts, USA & B. S. Kopp (pers. obs.) \\
Clamworm & Neanthes virens & Lodging at $\geq 3$ core $^{-1}$ & New Hampshire, USA & Davis \& Short (1997) \\
Lugworm & Arenciola marina & Burial & The Netherlands & Philippart (1994) \\
Burrowing shrimp & Callianassa californiensis & Burial & Washington, USA & Harrison (1987) \\
Green urchin & Strongylocentrotus spp. & Grazing & Alaska, USA & F. T. Short (pers. obs.) \\
Canada geese & Branta canadensis & Grazing & New England, USA & Buchsbaum (1987) \\
Brant & Branta bernicla & Grazing & British Colombia, Canada Baldwin \& Lovvorn (1994) \\
Trumpeter swan & Cygnus olor & Grazing & New England, USA & F. T. Short (pers. obs.) \\
Whooper swan & Cygnus cygnus & Grazing & Japan & Albertsen \& Mukai (1998) \\
& & & & \\
\hline
\end{tabular}

beds (Table 2). Sites that have been identified as potential eelgrass habitat in Phase I may not support eelgrass due to bioturbation activity (Davis et al. 1998). The type and magnitude of bioturbation (Table 2) can be difficult to quantify, and such information is not generally available in routine estuarine monitoring or existing data. Underwater visual (video or diver) surveys can be used to determine to what extent bioturbating organisms (crabs, worms and other fauna) inhabit a site. Epibenthic bioturbating organisms can be easily assessed via quadrat-sampling, while infaunal organism quantification requires core-sampling.

A final and critical step in assessing a site for eelgrass restoration is to conduct a test-transplant, in which the transplants respond to the prevailing environmental conditions and integrate the combination of site-specific factors which might limit their survival and growth. We believe that survival of test transplants provides the best indication of how well a large-scale transplant will succeed at a given site. Fonseca et al. (1998) recommend test-transplanting for projects larger than $0.2 \mathrm{ha}$, and we have found it to be important in our restorations in New Hampshire and Massachusetts (see 'Results and discussion').

Beyond the assessment of survival itself, measurements of eelgrass growth and leaf nitrogen content in eelgrass from test-transplants give a more detailed picture, distinguishing the likelihood of success among possible transplanting sites. To encompass site-specific differences, these detailed measurements are made relative to the same measurements at 1 or more local reference eelgrass beds. Eelgrass leaf growth is a wellestablished parameter for measuring plant activity, and reflects net photosynthetic aboveground production (Short 1987, Dennison 1990). Similarly, the nitrogen content of eelgrass leaf tissue is known to vary depending on nutrients available in the water column and sediments (Short 1987, Short et al. 1995); high nitrogen content can be an indicator of excess nutrient loading
(F.T.S. unpubl. data). The inclusion of eelgrass growth metrics and leaf nitrogen content are optional parameters in Phase II, and can be omitted if such analyses are not available; however, some resolution is lost.

For test-transplanting, a sufficient number of sites is recommended to insure that adequate areas receiving a high TSI will emerge. Eelgrass plants for the testtransplanting must come from the same donor site(s) that will be used when full-scale transplantation occurs, and be collected using non-destructive techniques (Davis \& Short 1997). Eelgrass shoots can be test-transplanted using any established method (Fonseca et al. 1998). We have test-transplanted using the TERFSTM ('transplanting eelgrass remotely with frame systems': registered trademark of the University of New Hampshire) method (Short et al. 1999, 2002) and the 'horizontal rhizome method' (Davis \& Short 1997) at $0.5 \mathrm{~m}$ intervals in $2 \times 2 \mathrm{~m}$ plots. Survival, shoot growth, and leaf nitrogen may be measured on the test-transplants (Short et al. 1993) as early as 4 wk after planting. If time allows, it is recommended that the determination of test-transplant survival be made after a full year to incorporate seasonal site variability that may ultimately impact restoration success.

Phase III: calculating the TSI score. In Phase III, the TSI score is calculated, again as a multiplicative index, for each test-transplant site (Table 3). The TSI is determined by combining the results of the PTSI, light measurements, bioturbation assessment, and various parameters that reflect the results of test-transplanting. Every site is assigned a rating for each parameter in Table 3. First, the PTSI rating is assigned: 0 if the PTSI score is $\leq 1 ; 1$ if the PTSI is 2 or $4 ; 2$ if the PTSI is $\geq 8$. TSI ratings for light are assigned as follows: 0 for light $<20 \%$ surface irradiance; 1 for light $\geq 20 \%$ surface irradiance (or if no data is available); 2 for light greater than light measured in reference eelgrass beds. The TSI rating for bioturbation is based on the number of bioturbating organisms observed at a site; 0 if abun- 
Table 3. Data from Phase II for calculation of the transplant suitability index (TSI) to select full-scale eelgrass transplant sites. Ratings for each component are multiplied to determine the TSI for each site. Maximum possible TSI score $=64$

\begin{tabular}{|c|c|c|}
\hline Parameter (source) & TSI rating & Reference \\
\hline PTSI & $\begin{array}{l}0 \text { for PTSI }=0-1 \\
1 \text { for PTSI }=2-4 \\
2 \text { for PTSI }=8-16\end{array}$ & \\
\hline $\begin{array}{l}\text { Light } \\
\text { (field data) }\end{array}$ & $\begin{array}{l}0 \text { for }<20 \% \text { surface irradiance } \\
1 \text { for } \geq 20 \% \text { surface irradiance or no data } \\
2 \text { for irradiance }>\text { reference eelgrass }\end{array}$ & $\begin{array}{l}\text { Dennison et al. (1993) } \\
\text { Zimmerman et al. (1995) }\end{array}$ \\
\hline $\begin{array}{l}\text { Bioturbation } \\
\text { (field data) }\end{array}$ & $\begin{array}{l}0 \text { for abundant } \\
1 \text { for present } \\
2 \text { for not present }\end{array}$ & $\begin{array}{l}\text { Fonseca et al. (1994) } \\
\text { Davis \& Short (1997) }\end{array}$ \\
\hline $\begin{array}{l}\text { Survival } \\
\text { (test-transplants) }\end{array}$ & $\begin{array}{l}0 \text { for }<20 \% \\
1 \text { for } 20-40 \% \\
2 \text { for }>40 \%\end{array}$ & \\
\hline $\begin{array}{l}\text { Growth } \\
\text { (test-transplants) }\end{array}$ & $\begin{array}{l}1 \text { for }<\text { mean }-1 \text { SD or no data } \\
2 \text { for } \geq \text { mean }-1 S^{a}\end{array}$ & $\begin{array}{l}\text { Short (1987) } \\
\text { Dennison (1990) }\end{array}$ \\
\hline $\begin{array}{l}\text { Leaf } \mathrm{N} \\
\text { (test-transplants) }\end{array}$ & $\begin{array}{l}1 \text { for }>\text { mean }+2 \mathrm{SD} \text { or no data } \\
2 \text { for } \leq \text { mean }+2 \mathrm{SD}^{\mathrm{a}}\end{array}$ & \\
\hline
\end{tabular}

dant bioturbators were observed, 1 for the observed presence of bioturbators; 2 if no bioturbating organisms were found.

After assessment of the test transplants, 0 is assigned for $<20 \%$ survival, 1 for 20 to $40 \%$ survival, and 2 for $>40 \%$ survival of the eelgrass planting units. Eelgrass growth is rated 1 if test transplant growth is less than the mean -1 SD of growth at the reference site, and 2 if it is greater than or equal to the mean $-1 \mathrm{SD}$. That is, the site receives a higher rating if its growth is closer to or exceeds the mean growth of the reference site. One standard deviation provides a lower limit that includes a reasonable number of equivalent samples (84\%), indicating sites where transplants could be expected to grow as well as natural beds. The TSI rating of 1 for leaf $\mathrm{N}$ values greater than the mean $+2 \mathrm{SD}$ of the reference gives a site a lower rating if nitrogen loading has resulted in an excess accumulation of nitrogen in leaf tissue. Otherwise, this parameter receives a rating of 2. Measures of growth and leaf $\mathrm{N}$ are optional aspects of the TSI which provide a finer resolution of the index; for this reason, if data are not available for these parameters, they are scored 1 and do not eliminate a site from further consideration.

The TSI score is calculated as follows: TSI $=$ PTSI $\times$ light $\times$ bioturbation $\times$ survival $\times$ growth $\times$ leaf $N$. Some of the parameters in the TSI that are involved in assessment of habitat conditions for eelgrass transplantation are redundant; however, they are included in the formulation to create a more robust index of site suitability. The TSI becomes zero and causes a site to be rejected from further consideration if the
PTSI is $\leq 1$, if light is below $20 \%$ surface irradiance, if bioturbation is abundant, or if low survival $(<20 \%)$ of test-transplants occurred (Table 3). Sites with the highest TSI score at the end of Phase III are then selected for full-scale eelgrass transplantation. The maximum TSI score possible is 64, although the maximum may be lower if optional parameters are excluded. Sites that receive values $<8$ (based on all 6 parameters) are typically rejected.

\section{RESULTS AND DISCUSSION}

\section{Two applications of the site-selection model}

Post hoc application to the Piscataqua River, New Hampshire

As a first assessment of the site-selection model, the TSI was calculated post hoc on the 5 eelgrass mitigation sites (Fig. 1). In the Port Project, a 2.52 ha eelgrass transplantation was conducted in the early 1990s. Transplantation initially took place at 5 sites, 2 of which proved successful in creating new eelgrass beds; 3 sites had almost complete failure (Davis \& Short 1997). We compared the predictions of the TSI with the monitored results of the 5 transplant sites.

PTSI for the Port Project: Most of the data required for post hoc application of the PTSI were available from monitoring the Port Project transplant sites, supplemented by long-term eelgrass information for the Great Bay Estuary (Table 4). Eelgrass distribution in- 


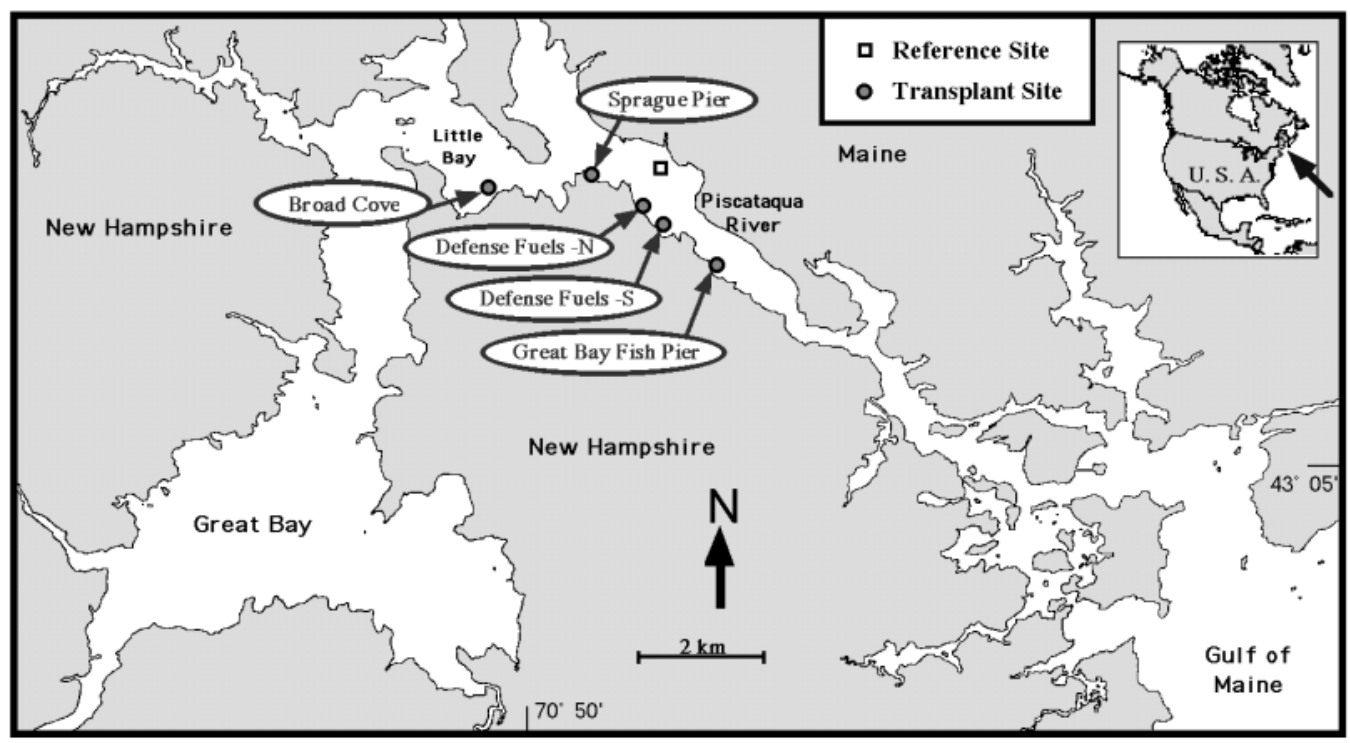

Fig. 1. Eelgrass transplant sites of New Hampshire Port Mitigation Project and reference site on the Maine side of the Piscataqua River

formation (historical and current) has been collected using aerial photography and ground truth assessments since 1980 (Nelson 1981, Short et al. 1986, 1993, 1998). The resulting maps became the basis for deciding whether or not the Port Project sites had been previously vegetated. Proximity to natural eelgrass beds was calculated for each of the transplant sites from the available eelgrass distribution data using a Geographic Information System (GIS) (Table 4).

Table 4. Data parameters and data sources of the PTSI for transplant sites in the post hoc analysis of the Port Project. Parameters are specific for conditions at the transplant sites in the Piscataqua River

\begin{tabular}{|ll|}
\hline Parameter (source) & PTSI rating \\
\hline Historical eelgrass distribution & 1 for previously unvegetated \\
$\quad$ (Short et al. 1986, 1993) & 2 for previously vegetated \\
Current eelgrass distribution & 0 for currently vegetated \\
(Short et al. 1998) & 1 for currently unvegetated \\
Proximity to natural eelgrass beds & 0 for $<100 \mathrm{~m}$ \\
(GIS calculation) & 1 for $\geq 100 \mathrm{~m}$ \\
Sediment & 0 for rock or cobble \\
(Davis 1999) & 1 for $>70 \%$ silt/clay \\
& 2 for cobble-free with $\leq 70 \%$ silt/clay \\
Wave exposure & 0 for $>$ mean +2 SD \\
(Davis 1999) & 1 for $\leq \mathrm{mean}+2$ SD \\
Water depth & 0 for $<-0.5 \mathrm{~m}$ or $>-2$ m MLW \\
(based on reference eelgrass bed) & 1 for $-0.5 \mathrm{~m}$ to $-0.75 \mathrm{~m}$ MLW \\
(Davis 1999) & 2 for $-0.75 \mathrm{~m}$ to $-1.5 \mathrm{~m}$ MLW \\
& 1 for $-1.5 \mathrm{~m}$ to -2 m MLW \\
Water quality & 0 meets $<3$ habitat requirements \\
(Batuik et al. 1992, Davis 1999) & 1 meets $3-4$ habitat requirements \\
& 2 meets 5 habitat requirements \\
aMean at local natural (reference) eelgrass beds
\end{tabular}

Sediment data for this application of the PTSI were collected from the transplant sites prior to transplantation (Table 4). For the wave-exposure parameter we used eelgrass distribution information (above) to estimate fetch (which was calculated for each site using NOAA navigation charts), and we then compared transplant sites to reference eelgrass beds. Three fetch measurements were used to obtain a mean for each site: greatest fetch, northeast fetch, and northwest fetch. The latter 2 directions were chosen because these are the headings from which the strongest storm winds impact this region.

Depth distribution of eelgrass beds, used in determining the water-depth parameter of the PTSI, was measured at transplant sites as well as reference eelgrass beds (Fig. 1), thereby identifying local depth limits (and replacing the general ratings in Table 1) for eelgrass in the Piscataqua River (Table 4). The PTSI rating for water quality of the Piscataqua River was based on the Chesapeake Bay determination of 'habitat requirements for SAV' (i.e. 'submerged aquatic vegetation'; Batiuk et al. 1992), applied to the water-quality information available for the Piscataqua River (Davis 1999). The site-specific ratings provide a translation of the qualitative general ratings of 'poor, fair, good' in Table 1. The PTSI ratings for water quality at 
the transplant sites were assigned according to the number of 'habitat requirements' satisfied by the data (Table 4).

In the early 1990s the transplanting sites for the Port Project were chosen using 'best professional judgement'; applying the site-selection model post hoc, all received rather high PTSI scores (Table 5). The PTSI analysis of the Port Project transplant sites shows 2 sites with PTSI scores of 16 and 3 sites with scores of 8 (Table 5). If one were using the PTSI before a transplanting project, all 5 sites would be selected for Phases II and III (field sampling and TSI scoring) based on their PTSI scores. If this were not a post hoc analysis, we would probably have many additional sites for PTSI evaluation, and most would have been eliminated by the Phase I evaluation.

Field data and test transplanting for the Port Project: Data collection for Phase II of this post hoc analysis was based primarily on Port Project monitoring (Table 6). Information on light condition at all 5 sites was monitored with the ENDECO 174 SSM (Davis 1999). Visual surveys were used before transplanting to determine the extent of bioturbating organisms at all 5 sites; green crabs Carcinus maenas and clam worms Neanthes virens were determined to be the primary bioturbating organisms (Table 2). In later monitoring of the Port Project, bioturbation was shown to be one of the primary factors causing transplant failure at some sites (Davis \& Short 1997, Davis et al. 1998). Green crab densities greater than $4.0 \mathrm{~m}^{-2}$ significantly reduced transplant survival (Davis et al. 1998). In addition to the visual survey, six $9 \mathrm{~cm}$ diameter benthic cores were collected from each site and sieved through a $1 \mathrm{~mm}$ mesh to quantify clam worms inhabiting the sites; these organisms are a significant source of bioturbation when they occur in densities $>1$ core $^{-1}$ (Davis 1999). Percent survival of eelgrass at the 5 sites was assessed on the transplants themselves (Davis \& Short 1997). Unfortunately, eelgrass transplant growth rates were not measured as part of the monitoring. Leaf $\mathrm{N}$ was analyzed as \% $\mathrm{N}$ of unfouled eelgrass leaf tissue.

TSI for the Port Project: Phase III combines the results of the field sampling information with those of the PTSI to calculate the TSI score, which is used to pri-

Table 5. Parameter ratings of the PTSI and the final PTSI score for the 5 transplant sites; post hoc analysis of the New Hampshire Port Project. Maximum possible PTSI $=16$

\begin{tabular}{|c|c|c|c|c|c|c|c|c|c|}
\hline Site no. & Site name & $\begin{array}{c}\text { Historical } \\
\text { eelgrass }\end{array}$ & $\begin{array}{l}\text { Current } \\
\text { eelgrass }\end{array}$ & Proximity & $\begin{array}{l}\text { Sediment } \\
\text { type }\end{array}$ & $\begin{array}{c}\text { Wave } \\
\text { exposure }\end{array}$ & $\begin{array}{l}\text { Water } \\
\text { depth }\end{array}$ & $\begin{array}{l}\text { Water } \\
\text { quality }\end{array}$ & $\begin{array}{l}\text { PTSI } \\
\text { score }\end{array}$ \\
\hline 1 & Great Bay Fish Pier & 2 & 1 & 1 & 2 & 1 & 2 & 2 & 16 \\
\hline 2 & Defense Fuels - South & 2 & 1 & 1 & 2 & 1 & 2 & 1 & 8 \\
\hline 3 & Defense Fuels - North & 2 & 1 & 1 & 2 & 1 & 2 & 2 & 16 \\
\hline 4 & Sprague Pier & 2 & 1 & 1 & 2 & 1 & 2 & 1 & 8 \\
\hline 5 & Broad Cove & 2 & 1 & 1 & 2 & 1 & 2 & 1 & 8 \\
\hline
\end{tabular}

Table 6. TSI calculation; post hoc application to the New Hampshire Port Project. Ratings for each parameter are multiplied to determine the TSI score for each site. Ref. mean: mean value for natural reference eelgrass beds. Maximum possible TSI score for this analysis $=32$, since data on eelgrass growth were not available; growth was rated 1 . Priority sites are those with TSI $\geq 16$; sites with a TSI $<16$ would be rejected

\begin{tabular}{|c|c|c|c|c|c|c|c|c|c|c|c|c|}
\hline \multirow{2}{*}{$\begin{array}{l}\text { Site } \\
\text { no. }\end{array}$} & \multirow[t]{2}{*}{ Site name } & \multicolumn{4}{|c|}{ TSI data } & \multirow[b]{2}{*}{$\begin{array}{c}\text { PTSI } \\
\text { (from } \\
\text { Table 5) }\end{array}$} & \multirow[b]{2}{*}{ Light } & \multicolumn{2}{|c|}{ — TSI rating _ } & \multirow{2}{*}{ Growth } & \multirow{2}{*}{$\overline{\text { Leaf } \mathrm{N}}$} & \multirow{2}{*}{$\begin{array}{r}\text { TSI } \\
\text { score }\end{array}$} \\
\hline & & $\begin{array}{l}\text { Light } \\
\text { (\% ref.) }\end{array}$ & $\begin{array}{c}\text { Bioturbation } \\
\left(\text { crabs m }^{-2}\right) \\
\left(\text { worms core }^{-1}\right)\end{array}$ & $\begin{array}{l}\text { Survi- } \\
\text { val } \\
(\%)\end{array}$ & $\begin{array}{c}\text { Leaf N } \\
(\%)\end{array}$ & & & $\begin{array}{l}\text { Biotur- } \\
\text { bation }\end{array}$ & $\begin{array}{l}\text { Survi- } \\
\text { val }\end{array}$ & & & \\
\hline 1 & Great Bay Fish pier & 110 & $\begin{array}{c}2 \\
1.3\end{array}$ & 80 & 1.37 & 2 & 2 & 1 & 2 & 1 & 2 & 16 \\
\hline 2 & Defense Fuels - South & 94 & $\begin{array}{c}3 \\
1.8\end{array}$ & 75 & 1.67 & 2 & 1 & 1 & 2 & 1 & 2 & 8 \\
\hline 3 & Defense Fuels - North & 120 & $\begin{array}{c}0 \\
1.0\end{array}$ & 95 & 2.10 & 2 & 2 & 2 & 2 & 1 & 2 & 32 \\
\hline 4 & Sprague Pier & 85 & $\begin{array}{c}5 \\
1.8\end{array}$ & 5 & 1.76 & 2 & 1 & 0 & 0 & 1 & 2 & 0 \\
\hline 5 & Broad Cove & 230 & $\begin{array}{c}0 \\
12.5\end{array}$ & 1 & 1.90 & 2 & 2 & 0 & 0 & 1 & 2 & 0 \\
\hline Ref. & mean $( \pm \mathrm{SD})$ & & & & $.04( \pm 0.04)$ & & & & & & & \\
\hline
\end{tabular}


oritize site-selection, in this case retrospectively. Based on their PTSI scores of 16 and 8, all sites received a TSI rating of 2 for this parameter (Tables $5 \& 6$ ). All sites had $>20 \%$ surface irradiance, and 3 sites had irradiance greater than the reference eelgrass beds, thus achieving a rating of 2 .

Sites were assigned a rating of 0 when crab densities were $>4.0 \mathrm{~m}^{-2}$ or Nereis virens densities were $474 \mathrm{~m}^{-2}$ (>3 core $^{-1}$ [abundant] see Tables $3 \& 6$ ), a rating of 1 when crab densities were 1 to $4 \mathrm{~m}^{-2}$ or $N$. virens densities were 0.5 to 3 core $^{-1}$ (present), and a rating of 2 if neither crabs $\left(<1 \mathrm{~m}^{-2}\right)$ nor worms $\left(<0.5\right.$ core $\left.^{-1}\right)$ were observed (bioturbation not present).

Percent survival was evaluated after the plants had been in place through the winter. Three sites, Great Bay Fish Pier, Defense Fuels-South, and Defense Fuels-North, had $>40 \%$ survival $(80,75$, and $95 \%$, respectively) for TSI ratings of 2, while 2 sites, Sprague Pier and Broad Cove, had survival rates of 5 and $1 \%$, respectively (rating 0). Shoot growth was not measured and received a rating of 1 . Leaf $\mathrm{N}$ received a rating of 2 at all 5 sites (Table 6).

Post hoc comparison: For comparison of the TSI score with the actual success of transplanting in the Port Project, the maximum achievable score was 32, because growth was not measured (Table 6). The TSI scores for Defense Fuels - North and Great Bay Fish Pier were 32 and 16, respectively. These 2 sites were predicted by the TSI to be priority sites for transplanting, and, since this is a post hoc application of the TSI, it can be reported that these 2 sites had the greatest success among all the transplant sites of the Port Project (Davis \& Short 1997, Short et al. 2000). Both sites have shown excellent survival, growth, and expansion of eelgrass. At these sites, the eelgrass, transplanted with $0.5 \mathrm{~m}$ spacing, has now expanded and coalesced to form dense beds.

Unfortunately, with 'best professional judgement' as our guide, we also transplanted 3 sites in the Port Project that failed. Defense Fuels - South scored well in the PTSI but low in the TSI because of low light (not greater than the reference sites) and bioturbation. This site received a post hoc TSI score of 8 , below the cutoff $(<16)$ for transplantation, and showed no long-term eelgrass survival. Both the Sprague Pier and Broad Cove sites received a TSI of 0 , and would have been rejected by the model as transplant sites. The Sprague Pier site would have been rejected because of bioturbation by green crabs (Davis \& Short 1997), and Broad Cove because of bioturbation by clam worms (Davis 1999). Transplanting at both sites failed due to bioturbation. Overall, the post hoc comparison of the siteselection model predictions to actual Port Project results showed a good match, with all transplanting successes and failures predicted by the TSI.

\section{Application of the TSI to New Bedford Harbor, Massachusetts}

In the New Bedford Harbor (NBH) Eelgrass Restoration Project, we used the site-selection model to identify the suitability of sites in New Bedford, Dartmouth, and Fairhaven, Massachusetts, as locations for eelgrass transplanting (Fig. 2). New Bedford Harbor is a highly impacted industrial estuary that lost much of its eelgrass due to poor water quality resulting from anthropogenic activities. In addition, there has been a high degree of industrial contamination of the sediments (Costa et al. 1996). Recent improvements in sewage treatment have reversed poor water-quality conditions, making parts of the outer harbor suitable once again for eelgrass growth. The $\mathrm{NBH}$ project investigated the best areas for reestablishment of eelgrass habitat in the outer harbor and adjacent Clarks Cove, and initiated a transplanting effort. The $\mathrm{NBH}$ project overlapped with our development of the TSI.

$\mathrm{NBH}$ is a well-studied estuary, with much historical documentation and long-term monitoring data available (Table 7). A PTSI was calculated for 20 possible eelgrass transplant sites using existing data (Fig. 2). Because the timing of information availability overlapped with the window for eelgrass test-transplanting in $\mathrm{NBH}$, we test-transplanted all 20 sites in summer 1998. Even though the TSI evaluation of all NBH sites was not completed until fall 1999, project requirements dictated full-scale transplanting at 4 sites beginning in the spring of that year. Below, we use the site-selection model to evaluate the NBH transplant sites and then compare its predictions to results from our first year of transplanting.

PTSI for New Bedford Harbor: Of the 20 sites evaluated with the PTSI, 16 sites were identified as previously having eelgrass (Costa 1988, NBH Shellfish Warden pers. comm.) and rated (Table 8). For the parameters of current eelgrass distribution (Costello 1997) and proximity to natural eelgrass beds (calculated using GIS), all 20 sites received a rating of 1 (Table 8). Sediment distribution data (Vanesse Hangen Brustlin, Inc. 1996) indicated that all sites had good sediment conditions for eelgrass growth and rated 2. Evaluation of each site for wave-exposure relative to our reference/donor site off West Island (Fig. 2) suggested that none of the 20 sites would experience detrimental wave exposure conditions; all were rated 1. Water depth varied between sites, with 13 of the sites within the best water depth range for eelgrass growth, determined to be -2 to -5 feet $(-0.61$ to $-1.52 \mathrm{~m})$ MLW from assessment of existing eelgrass beds in NBH. These 13 sites were rated 2 for depth, while all other sites were rated 1 because of shallower or deeper water at the site (Tables $7 \& 8$ ). As it turned out, the available water- 


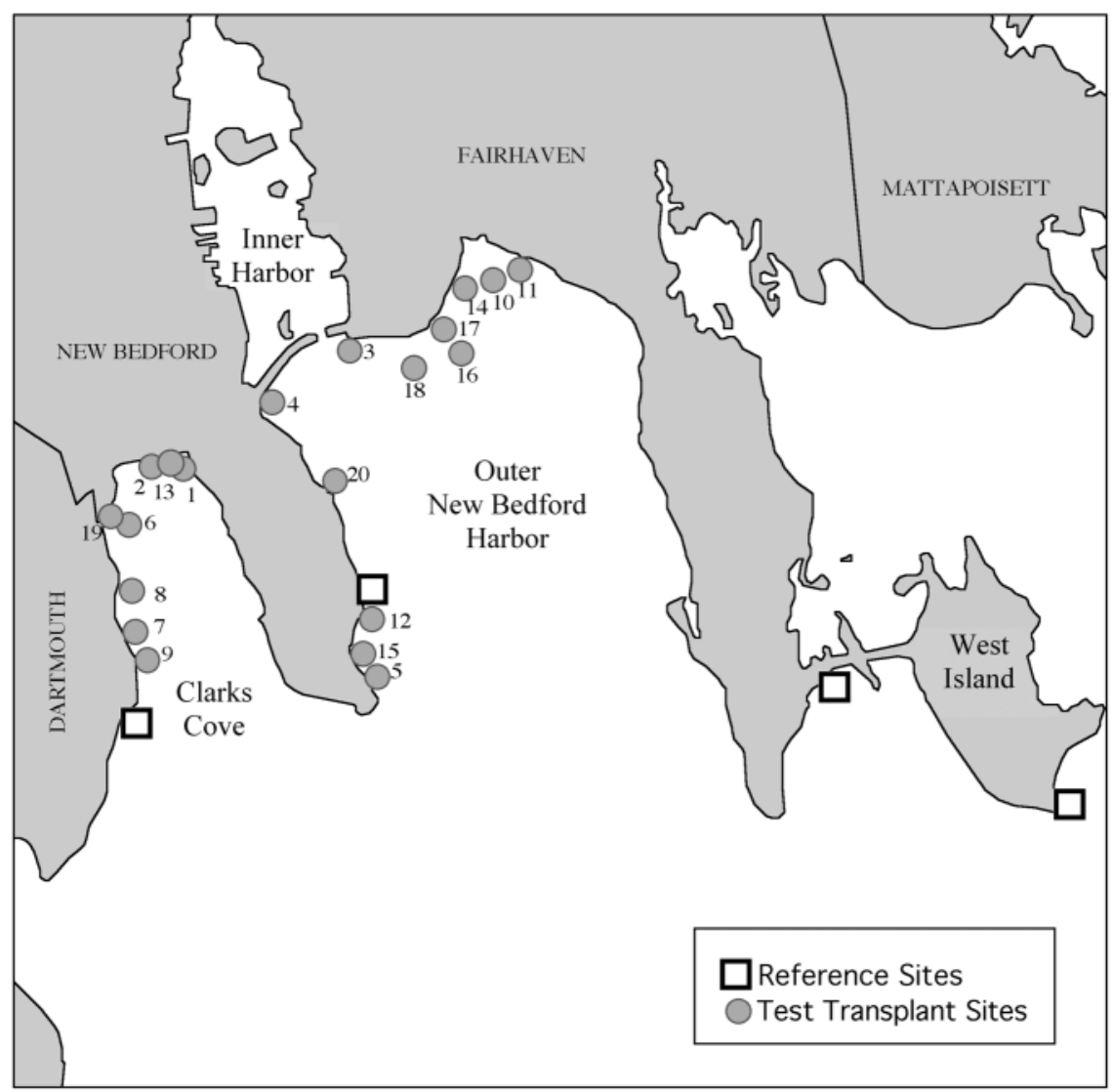

Fig. 2. Eelgrass test transplant sites and reference beds in New Bedford Harbor study area, Buzzards Bay, Massachusetts, USA, 1998

Table 7. Data parameters and data sources of the PTSI used for identification of potential transplant sites in New Bedford Harbor

\begin{tabular}{|ll|}
\hline Parameter (source) & Rating \\
\hline Historical eelgrass distribution & 1 for previously unvegetated \\
(Costa 1988 and credible anecdotal evidence) & 2 for previously vegetated \\
Current eelgrass distribution & 0 for currently vegetated \\
(Costello 1997 and field surveys) & 1 for currently unvegetated \\
Proximity to natural eelgrass beds & 0 for $<100 \mathrm{~m}$ \\
(GIS calculation) & 1 for $\geq 100 \mathrm{~m}$ \\
Sediment & 0 for rock or cobble \\
(Vanesse Hangen Brustlin, & 1 for $>70 \%$ silt/clay \\
Inc. 1996 and field surveys) & 2 for cobble free with $\leq 70 \%$ silt/clay \\
Wave exposure & 0 for $>$ mean +2 SD \\
(GIS calculations) & 1 for $\leq$ mean +2 SD \\
Water depth & 0 for shallower than $-1^{\prime}$ MLW \\
(bathymetry: Vanesse Hangen Brustlin, & 1 for $-1^{\prime}$ to $-2^{\prime}$ MLW \\
Inc. 1996, Costa 1988) & 2 for $-2^{\prime}$ to $-5^{\prime}$ MLW \\
& 1 for $-5^{\prime}$ to $-6^{\prime}$ MLW \\
Water quality: eutrophication index & 0 for eutrophication index $<35$ \\
(phytoplankton pigments, DIN, TON, Secchi & 1 for eutrophication index $35-65$ \\
depth, Costa et al. 1996, Howes et al. 1999) & 2 for eutrophication index $>65$ \\
a Mean at local natural (reference) eelgrass beds & \\
\hline
\end{tabular}

quality data and the calculated eutrophication index were not ideal for our analysis: the low resolution of the data and offshore location of water quality stations (Costa et al. 1996) meant the results were not directly applicable to our 20 nearshore sites. As a result, we had no data to document nearshore water-quality conditions and assigned all the sites a rating of 1 for water quality. The calculation of the PTSI score from these ratings resulted in $11 \mathrm{NBH}$ sites with a PTSI score of 8 (Table 8), high enough to move on to Phase II and TSI evaluation.

TSI for New Bedford Harbor: Because we did not have the final site-selection model before the season for test-trans- 
planting in NBH, we actually test-transplanted at all 20 sites. Thus, although the PTSI indicated that only the 11 sites receiving scores of $\geq 8$ should go on to Phase II (Table 8), we carried all 20 sites through the entire analysis. In the summer of 1998, we evaluated all the TSI parameters, including 1 mo survival. These parameters, as well as the leaf $\mathrm{N}$ content (no growth measurements were made), varied between sites (Table 9). The data in Table 9 were then used to assign ratings based on the criteria in Table 3 .

The first parameter for TSI ratings is based on the PTSI, where 11 sites were rated 2; other sites received a rating of 1 (Tables $8 \& 9$ ). Light was measured relative to irradiance conditions at natural eelgrass beds through comparative deployment of underwater LiCor $4 \pi$ light sensors at the 15 sites where survival of the test transplants seemed most successful. Project resources, and (at 1 site) heavy use by recreational clam diggers, precluded assessment of light conditions at the 5 remaining sites. Light ranged from 28 to $208 \%$ of light at the natural eelgrass bed (Table 9). All sites with light greater than the natural bed received a rating of 2. Because in NBH no measurements of light relative to surface irradiance were made, evaluation of sites relative to the $20 \%$ surface irradiance criteria (Table 3) was not possible and the sites received a rating of 1.

Bioturbation was evaluated at all $20 \mathrm{NBH}$ sites based on assessment of the presence of the primary local bioturbating organism, the spider crab Libinia spp.
(Table 2). A rating of 0 was given for abundant crabs (densities $>4 \mathrm{~m}^{-2}$ ), 1 was given for crabs present ( 1 to $4 \mathrm{~m}^{-2}$ ), and 2 for crabs not present (based on Davis et al. 1998). No other type of bioturbation was observed in NBH.

Test-transplanting at each of the 20 sites was conducted using the TERFS ${ }^{\mathrm{TM}}$. Test-transplant survival was assessed after 1 mo (Table 9). Survival ranged from 0 to $85 \%$ and was given a TSI rating of 0,1 , or 2 (Tables $3 \&$ 9). Growth, one of the optional parameters, was not measured and rated 1 . Leaf $\mathrm{N}$ data were compared with leaf $\mathrm{N}$ content at the reference sites (Tables 3 \& 9).

Calculation of the final TSI score (Phase III) was accomplished by multiplying together the TSI ratings for each site (Table 9). Since only 5 of the 6 parameters of the TSI were measured (with growth receiving a default rating of 1 at each site), the highest possible TSI score was 32 . For NBH, sites with a TSI score $<8$ were not recommended for transplanting based on the $1 \mathrm{mo}$ survival evaluation. Sites with TSI scores $\geq 16$ were considered priority sites for full-scale transplanting. Of the 20 sites, 6 were predicted by the site-selection model to be priority eelgrass transplanting sites: Sites $3,8,18$, and 20 all received a TSI score of 32; Sites 7 and 9 received a score of 16 . However, were the TSI analysis (Table 9) to be recalculated with the nowavailable 1 yr transplant survival numbers, Sites 7 and 9 would be eliminated, due to a rating of zero for survival.

Table 8. Parameter ratings of PTSI for the 20 test-transplant sites in New Bedford Harbor, 1998. Maximum possible PTSI = 16

\begin{tabular}{|c|c|c|c|c|c|c|c|c|c|}
\hline $\begin{array}{l}\text { Site } \\
\text { no. }\end{array}$ & Site name & $\begin{array}{l}\text { Historical } \\
\text { eelgrass }\end{array}$ & $\begin{array}{l}\text { Current } \\
\text { eelgrass }\end{array}$ & Proximity & $\begin{array}{l}\text { Sediment } \\
\text { type }\end{array}$ & $\begin{array}{l}\text { Wave } \\
\text { exposure }\end{array}$ & $\begin{array}{l}\text { Water } \\
\text { depth }\end{array}$ & $\begin{array}{l}\text { Water } \\
\text { quality }\end{array}$ & $\begin{array}{l}\text { PTSI } \\
\text { score }\end{array}$ \\
\hline 1 & Clarks Cove-East & 2 & 1 & 1 & 2 & 1 & 2 & 1 & 8 \\
\hline 2 & Clarks Cove-West & 2 & 1 & 1 & 2 & 1 & 2 & 1 & 8 \\
\hline 3 & Fort Phoenix - West & 2 & 1 & 1 & 2 & 1 & 2 & 1 & 8 \\
\hline 4 & Fred's Rock & 2 & 1 & 1 & 2 & 1 & 2 & 1 & 8 \\
\hline 5 & Tabor Park Pier & 1 & 1 & 1 & 2 & 1 & 2 & 1 & 4 \\
\hline 6 & Town Line-Deep & 2 & 1 & 1 & 2 & 1 & 1 & 1 & 4 \\
\hline 7 & Dartmouth-Condos & 2 & 1 & 1 & 2 & 1 & 2 & 1 & 8 \\
\hline 8 & Dartmouth - North & 2 & 1 & 1 & 2 & 1 & 2 & 1 & 8 \\
\hline 9 & Dartmouth-Stairs & 2 & 1 & 1 & 2 & 1 & 1 & 1 & 4 \\
\hline 10 & Fairhaven-Middle & 1 & 1 & 1 & 2 & 1 & 1 & 1 & 2 \\
\hline 11 & Fairhaven-East & 1 & 1 & 1 & 2 & 1 & 2 & 1 & 4 \\
\hline 12 & Clarks Point_-East & 2 & 1 & 1 & 2 & 1 & 1 & 1 & 4 \\
\hline 13 & Clarks Cove-Middle & 2 & 1 & 1 & 2 & 1 & 1 & 1 & 4 \\
\hline 14 & Fairhaven-West & 1 & 1 & 1 & 2 & 1 & 1 & 1 & 2 \\
\hline 15 & Tabor Park Jetty ${ }^{a}$ & 2 & 1 & 1 & 2 & 1 & 2 & 1 & 8 \\
\hline 16 & Fort Phoenix - Deep & 2 & 1 & 1 & 2 & 1 & 1 & 1 & 4 \\
\hline 17 & Fort Phoenix — Shallow & 2 & 1 & 1 & 2 & 1 & 2 & 1 & 8 \\
\hline 18 & Fort Phoenix —-Middle & 2 & 1 & 1 & 2 & 1 & 2 & 1 & 8 \\
\hline 19 & Town Line-Shallow & 2 & 1 & 1 & 2 & 1 & 2 & 1 & 8 \\
\hline 20 & Billy Woods & 2 & 1 & 1 & 2 & 1 & 2 & 1 & 8 \\
\hline
\end{tabular}


Table 9. TSI calculation for eelgrass restoration sites in New Bedford Harbor. Ratings for each parameter are multiplied to determine TSI score for each site. Ref. mean: mean value for natural reference eelgrass beds. Maximum possible TSI score for this analysis $=32$, since data on eelgrass growth were not available; growth was rated 1 . Priority sites are those with TSI $\geq 16$; sites with a TSI $<16$ would be rejected. na: data not available

\begin{tabular}{|c|c|c|c|c|c|c|c|c|c|c|c|c|}
\hline \multirow{2}{*}{$\begin{array}{l}\text { Site } \\
\text { no. }\end{array}$} & \multirow{2}{*}{ Site name } & \multicolumn{4}{|c|}{$\longrightarrow$ TSI data $\longrightarrow$} & \multirow{2}{*}{$\begin{array}{l}\text { PTSI } \\
\text { (from } \\
\text { Table 8) }\end{array}$} & \multirow{2}{*}{ Light } & \multicolumn{2}{|c|}{ — TSI rating } & \multirow[b]{2}{*}{ Growth } & \multirow[b]{2}{*}{ Leaf $\mathrm{N}$} & \multirow{2}{*}{$\begin{array}{r}\text { TSI } \\
\text { score }\end{array}$} \\
\hline & & $\begin{array}{l}\text { Light } \\
\text { (\% ref.) }\end{array}$ & $\begin{array}{l}\text { Bioturbation } \\
\left(\text { crabs } \mathrm{m}^{-2}\right)\end{array}$ & $\begin{array}{c}\text { Survi- } \\
\text { val after } \\
1 \text { mo (\%) }\end{array}$ & $\begin{array}{l}\text { Leaf } N \\
(\%)\end{array}$ & & & $\begin{array}{l}\text { Biotur- } \\
\text { bation }\end{array}$ & $\begin{array}{l}\text { Survi- } \\
\text { val }\end{array}$ & & & \\
\hline 1 & Clarks Cove-East & 72 & 1 & 50 & 1.37 & 2 & 1 & 1 & 2 & 1 & 2 & 8 \\
\hline 2 & Clarks Cove-West & 72 & 1 & 31 & 1.67 & 2 & 1 & 1 & 1 & 1 & 2 & 4 \\
\hline 3 & Fort Phoenix-West & 208 & 0 & 52 & 1.52 & 2 & 2 & 2 & 2 & 1 & 2 & 32 \\
\hline 4 & Fred's Rock & na & 0 & 0 & 1.76 & 2 & 1 & 2 & 0 & 1 & 2 & 0 \\
\hline 5 & Tabor Park Pier & na & 4 & 47 & 0.93 & 1 & 1 & 0 & 2 & 1 & 2 & 0 \\
\hline 6 & Town Line-Deep & 28 & 0 & 47 & 1.05 & 1 & 1 & 2 & 2 & 1 & 2 & 8 \\
\hline 7 & Dartmouth-Condos & 103 & 0 & 36 & 0.94 & 2 & 2 & 2 & 1 & 1 & 2 & 16 \\
\hline 8 & Dartmouth—North & 103 & 0 & 83 & 0.86 & 2 & 2 & 2 & 2 & 1 & 2 & 32 \\
\hline 9 & Dartmouth-Stairs & 103 & 0 & 85 & 0.90 & 1 & 2 & 2 & 2 & 1 & 2 & 16 \\
\hline 10 & Fairhaven_Middle & 72 & 4 & 15 & 0.64 & 1 & 1 & 0 & 0 & 1 & 2 & 0 \\
\hline 11 & Fairhaven-East & 72 & 4 & 19 & 0.85 & 1 & 1 & 0 & 0 & 1 & 2 & 0 \\
\hline 12 & Clarks Point_East & na & 0 & 41 & 0.66 & 1 & 1 & 2 & 2 & 1 & 2 & 8 \\
\hline 13 & Clarks Cove-Middle & 72 & 3 & 13 & 0.75 & 1 & 1 & 1 & 0 & 1 & 2 & 0 \\
\hline 14 & Fairhaven-West & 72 & 5 & 24 & 0.94 & 1 & 1 & 0 & 0 & 1 & 2 & 0 \\
\hline 15 & Tabor Park Jetty & 45 & 0 & 22 & 0.94 & 2 & 1 & 2 & 0 & 1 & 2 & 0 \\
\hline 16 & Fort Phoenix - Deep & 46 & 0 & 48 & 0.80 & 1 & 1 & 2 & 2 & 1 & 2 & 8 \\
\hline 17 & Fort Phoenix - Shallow & na & 2 & 10 & 0.80 & 2 & 1 & 1 & 0 & 1 & 2 & 0 \\
\hline 18 & Fort Phoenix_Middle & 208 & 0 & 81 & 0.88 & 2 & 2 & 2 & 2 & 1 & 2 & 32 \\
\hline 19 & Town Line-Shallow & na & 0 & 22 & 1.05 & 2 & 1 & 2 & 0 & 1 & 2 & 0 \\
\hline \multirow[t]{2}{*}{20} & Billy Woods & 102 & 0 & 80 & 1.02 & 2 & 2 & 2 & 2 & 1 & 2 & 32 \\
\hline & Ref. mean $( \pm \mathrm{SD})$ & & & & $42( \pm 0.41)$ & & & & & & & \\
\hline
\end{tabular}

Comparison of the site-selection model and transplant results for New Bedford Harbor: Full-scale eelgrass transplantation in NBH began in the spring of 1999 with the planting of 4 sites to meet our first-year requirements. TERFS ${ }^{\mathrm{TM}}$ were used (160 per half acre [ 0.2 ha] site) for full-scale transplantation at Sites 3, 8, 18 , and 20, subsequently site choices confirmed by the TSI. Of the 4 sites transplanted in 1999, 2 (Sites 3 and 18) showed excellent eelgrass survival after 3 mo and continue to thrive. The other 2 sites failed. Site 8 experienced an extensive bloom of Codium fragile, a rapidly spreading exotic green algal species. C. fragile smothered the eelgrass transplants at Site 8, eliminating the transplanted bed completely. Some ecological conditions harmful to eelgrass transplants are episodic, and although the test transplants survived at this site, the macroalgal bloom that destroyed the full transplanting was unpredictable. Site 20 lost the majority of eelgrass transplants, but we do not know why. Testtransplants showed $75 \%$ survival after $1 \mathrm{yr}$, but the full transplantation failed, and surviving test-transplants did not live for a second year. Unlike Site 8, we cannot explain the eelgrass loss at Site 20, and will conduct additional test plantings there in the future. Full-scale eelgrass transplantation at locations chosen using the TSI in NBH in 2000 resulted in 1 yr survival at 3 of 4 sites. Considering both years of transplanting, we had an overall transplant success at 5 of 8 sites, or $62 \%$, using the site-selection model.

\section{Overview of the transplant suitability index}

In both the Port Project and NBH, some parameters of the TSI provided differentiation while others did not, but we believe that all the parameters can potentially contribute to successful site-selection for transplanting eelgrass. Future applications of the model will probably refine the index. As with evaluation of restoration success (Short et al. 2000), siteselection and the parameters of the TSI require comparison with local, natural, reference beds of eelgrass. Natural beds are dynamic integrators of local conditions, and comparison with these as a reference incorporates into site-selection the inherent variability that must be considered when dealing with living systems. The TSI was developed and tested in the northeastern US, and its application beyond this region requires additional testing and evaluation. However, the approach provides a basis and framework for models applicable to other seagrass species and other regions. 


\section{Conclusions}

Overall, our site-selection model resulted in $62 \%$ transplant site success in NBH which, although not ideal, is an improvement over previous attempts by ourselves and others in the northeastern US to select multiple eelgrass transplant sites (averaging 25\% transplant sucess: Table 10). Also, the post hoc analysis of the NH Port Project sites confirmed transplant success at both of the 2 sites chosen by the site-selection model and predicted the 3 failed sites. We believe this is a useful model for site-selection of eelgrass transplant efforts, making the best use of already available information and including the critical step of test-transplanting. No model can account for every eventuality (although other parameters could be incorporated to improve the model), but ours is likely to save money and time when eelgrass transplanting is undertaken. Our site-selection approach could also be applicable to other types of habitat restoration. By incorporating literature, data from reference sites, and simple field measurements, a quantitative assessment of the key factors influencing habitat development could be invaluable when considering the choice of sites for any habitat restoration.
Acknowledgements. The initial site-selection model development was funded by the National Oceanic and Atmospheric Administration through the National Estuarine Research Reserve Program (Grant No. NA57OR0349). The Department of Transportation and Port Authority, State of New Hampshire, funded the NH Port Mitigation Project and is now supporting the monitoring program. Dr Weldon Bosworth of Dames \& Moore and Mr Dan McHugh of Great Meadow Farm were valuable consultants in the NH Port Mitigation Project. The restoration of eelgrass in New Bedford Harbor, Massachusetts, is funded by the New Bedford Harbor Trustees Council. Thanks to Mr John Catena and Dr Jack Terrill for assistance in the NBH Project. Support was also made available by the University of New Hampshire, Jackson Estuarine Laboratory. Thanks to the many UNH students who assisted in these projects, the Coalition for Buzzard's Bay, and many NHB volunteers. This is Jackson Estuarine Laboratory contribution number 361 .

\section{LITERATURE CITED}

Adamowics SC (1994) Eelgrass Transplant Project: Brushneck and Buttonwoods Coves, Greenwich Bay. Report to the Rhode Island Department of Environmental Management, Providence. Narragansett Bay Project

Albertsen J, Mukai H (1998) Whooper swans feeding on eelgrass in Akkeshi Estuary, Northern Japan. In: Fortes M (ed) Abstract. 3rd International Seagrass Biology Workshop. National Committee on Marine Sciences, Quezon City, Philippines, p 52

Table 10. Success of eelgrass restoration projects in the northeastern US. Sites include full-scale transplant efforts (hectares) and test-transplants of less than 0.01 ha per location $(\mathrm{T})$

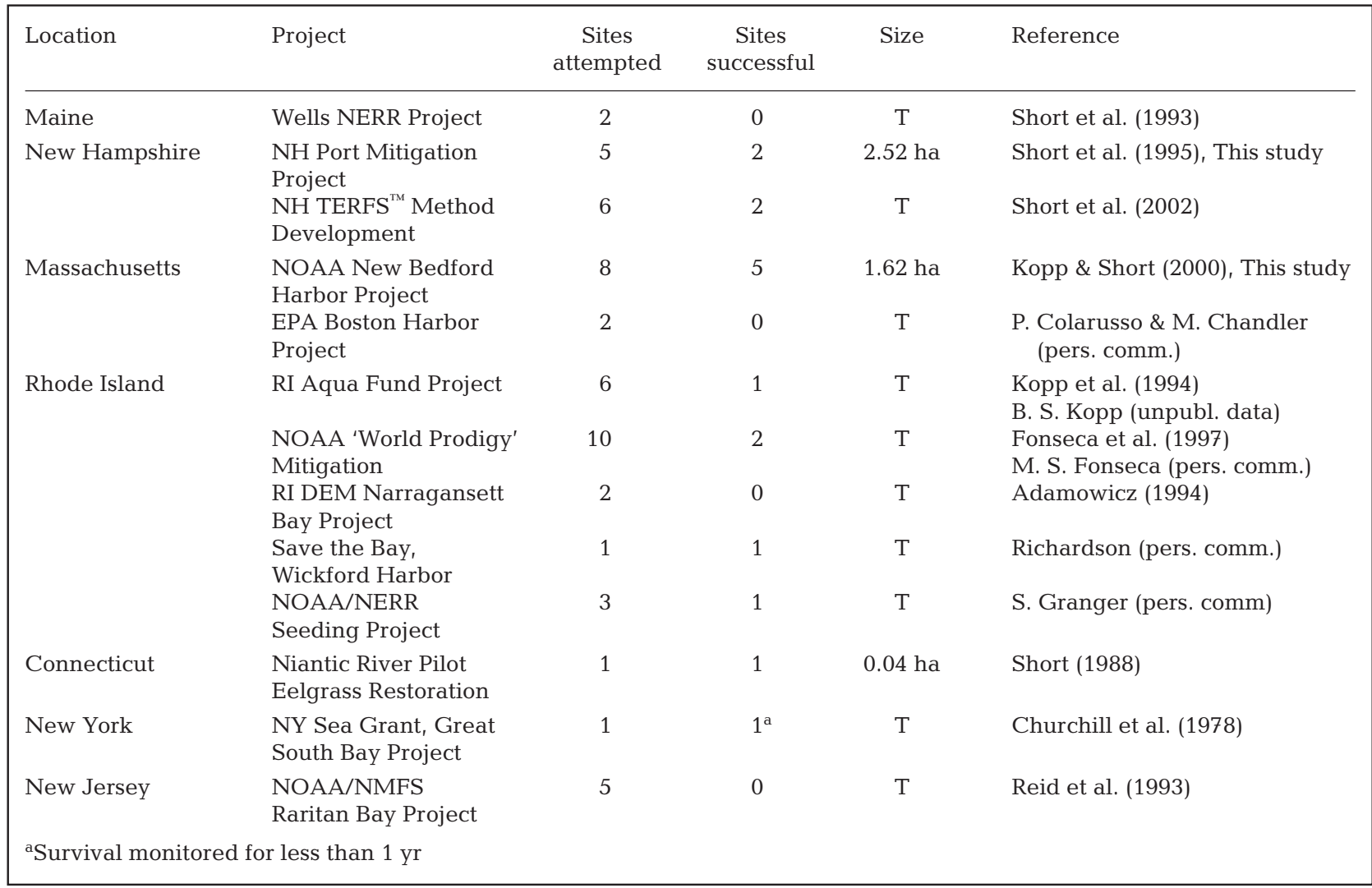


Baldwin JR, Lovvorn JR (1994) Expansion of seagrass habitat by the exotic Zostera japonica and its use by dabbling ducks and brant in Boundary Bay, British Columbia. Mar Ecol Prog Ser 103:119-127

Batiuk RA, Orth RJ, Moore KA, Dennison WC, Stevenson JC, Staver LW, Carter V, Rybicki NB, Hickman RE, Kollar S, Bieber S, Heasly P (1992) Chesapeake Bay submerged aquatic vegetation habitat requirements and restoration targets: a technical synthesis. US EPA, Annapolis, MD. CBP/TRS 83/92

Buchsbaum R (1987) The geese and the grass. Sanctuary 27: 7-9

Christiansen C, Christoffersen H, Dalsgaard J, Nornberg P (1981) Coastal nearshore changes correlated with dieback in eelgrass (Zostera marina). Sediment Geol 28: 168-178

Churchill AC, Cok AE, Riner MI (1978) Stabilization of subtidal sediments by the transplantation of the seagrass Zostera marina L. New York Sea Grant, Stonybrook NY. NYSSGP-RS-78-15

Costa JE (1988) Eelgrass in Buzzards Bay: distribution, production and historical changes in abundance. EPA Rep No. 503/4-88-002. US EPA Region 1, Boston

Costa JE, Howes BL, Giblin AE, Valiela I (1992) Monitoring nitrogen and indicators of nitrogen loading to support management action in Buzzards Bay. In: McKenzie DH, Hyatt DE, McDonald VJ (eds) Ecological indicators. Elsevier Applied Science, New York, p 499-531

Costa JE, Howes BL, Gunn E (1996) Report of the Buzzards Bay Citizens' Water Quality Monitoring Program 1992-1995. Coalition for Buzzards Bay, New Bedford, MA

Costello C (1997) Rooted vascular aquatic vegetation mapping in Massachusetts. Coastal Change Analysis Program (C-CAP) Annual Meeting. Rep February 12-14, 1997. NOAA, Charleston, SC

Davis RC (1999) The effects of physical and biological site characteristics on the survival and expansion of transplanted eelgrass (Zostera marina L.). PhD dissertation. University of New Hampshire, Durham

Davis RC, Short FT (1997) Restoring eelgrass (Zostera marina L.) habitat using a revised transplanting technique: the horizontal rhizome method. Aquat Bot 59:1-16

Davis RC, Short FT, Burdick DM (1998) Quantifying the effects of green crab damage to eelgrass transplants. Restor Ecol 6:297-302

den Hartog C (1994) The dieback of Zostera marina in the 1930 's in the Wadden Sea: an eye witness account by A. van der Werff. Neth J Aquat Ecol 28:51-54

Dennison WC (1987) Effects of light on seagrass photosynthesis, growth and depth distribution. Aquat Bot 27:15-26

Dennison WC (1990) Seagrass: leaf growth. In: Phillips RC, McRoy CP (eds) Seagrass research methods. UNESCO Press, Paris

Dennison WC, Orth RJ, Moore KA, Stevenson JC, Carter V, Kollar S, Bergstrom PW, Batiuk RA (1993) Assessing water quality with submersed aquatic vegetation. Bioscience 43 : 86-94

Duarte CM (1991) Seagrass depth limits. Aquat Bot 40: 363-377

Duarte CM (1995) Submerged aquatic vegetation in relation to different nutrient regimes. Ophelia 41:87-112

Fonseca MS (1992) Restoring seagrass systems in the United States. In: Thayer GW (ed) Restoring the nation's marine environment, Maryland Sea Grant, College Park, p 79-110

Fonseca MS, Kenworthy WJ, Courtney FX, Hall MO (1994) Seagrass planting in the Southeastern United States: methods for accelerating habitat development. Restor Ecol 2:198-212

Fonseca MS, Kenworthy WJ, Courtney FX (1996) Development of planted seagrass beds in Tampa Bay, Florida, USA. I. Plant components. Mar Ecol Prog Ser 132:127-139

Fonseca MS, Kenworthy WJ, Thayer GW, Catena JG, Scope JA (1997) Trip Report to NOAA Restoration Center on World Prodigy Eelgrass Planting Project: Narragansett Bay, RI. NOAA, Beaufort, NC

Fonseca MS, Kenworthy WJ, Thayer GW (1998) Guidelines for conservation and restoration of seagrass in the United States and adjacent waters. NOAA/NMFS Coastal Ocean Program Decision Analysis Series, No. 12. NOAA Coastal Ocean Office, Silver Spring, MD

Harrison PG (1987) Natural expansion and experimental manipulation of seagrass (Zostera spp.) abundance and the response of infaunal invertebrates. Estuar Coast Shelf Sci 24:799-812

Harrison PG (1990) Variations in success of eelgrass transplants over a five-years' period. Environ Conserv 17(2): 157-163

Heck KL Jr, Able KW, Roman CT, Fahay MP (1995) Composition, abundance, biomass and production of macrofauna in a New England estuary: comparisons among eelgrass meadows and other nursery habitats. Estuaries 18(2): 379-389

Howes BL, Williams T, Rasmussen M (1999) Baywatchers. II. nutrient related water quality of Buzzards Bay embayments: a synthesis of Baywatchers monitoring 1992-1998. The Coalition for Buzzards Bay. New Bedford, MA

Keddy PA (1982) Quantifying within-lake gradients of wave energy: interrelationships of wave energy, substrate particle size and shoreline plants in Axe Lake, Ontario. Aquat Bot 14:41-58

Kemp WM, Boyton WR, Stevenson JC, Twilley RR, Means JC (1983) The decline of submerged vascular plants in the upper Chesapeake Bay: summary of results concerning possible causes. Mar Technol Soc J 7:78-89

Kenworthy WJ, Fonseca M (1977) Reciprocal transplant of the seagrass Zostera marina L. Effect of substrate on growth. Aquaculture 12:197-213

Koch EW (1999) Water flow in tide and wave dominated beds of the seagrass Thalassia testudinum. Abstract. 15th Biennial International Conference. Estuarine Research Federation, New Orleans

Kopp BS (1999) Effects of nitrate enrichment and shading on physiological and biochemical properties of eelgrass (Zostera marina L.). PhD dissertation, University of Rhode Island, Kingston

Kopp BS, Short FT (2000) New Bedford Harbor Eelgrass Restoration Project. Progress Report to the New Bedford Harbor Trustees Council. Jackson Estuarine Laboratory, Durham, NH

Kopp BS, Doherty AM, Nixon SW (1994) A guide to site selection for eelgrass restoration Projects in Narragansett Bay, Rhode Island. Technical Report to the Narragansett Bay Project. University of Rhode Island, Narragansett

Lee KS, Dunton KH (1996) Production and carbon reserve dynamics of the seagrass Thalassia testudinum in Corpus Christi Bay, Texas, USA. Mar Ecol Prog Ser 143:201-210

Molenaar H, Meinesz A (1995) Vegetative reproduction in Posidonia oceanica: survival and development of transplanted cuttings according to different spacings, arrangements and substrates. Bot Mar 38:313-322

Murphey PL, Fonseca MS (1995) Role of high and low energy seagrass beds as nursery areas for Penaeus duorarum in North Carolina. Mar Ecol Prog Ser 121:91-98 
Nelson JI (1981) Inventory of natural resources of Great Bay estuarine system. New Hampshire Fish and Game Department, Concord

Olesen B (1996) Regulation of light attenuation and eelgrass Zostera marina depth distribution in a Danish embayment. Mar Ecol Prog Ser 134:187-194

Orth RJ (1975) Destruction of eelgrass, Zostera marina, by the cownose ray, Rhinoptera bonasus, in the Chesapeake Bay, Virginia. Chesapeake Sci 16:205-208

Orth RJ, Heck KL Jr, van Montfrans J (1984) Faunal communities in seagrass beds: a review of the influence of plant structure and prey characteristics on predator-prey relationships. Estuaries 7:339-350

Orth RJ, Luckenbach M, Moore KA (1994) Seed dispersal in a marine macrophyte: implications for colonization and restoration. Ecology 75:1297-1939

Philippart CJM (1994) Interactions between Arenicola marina and Zostera noltii on a tidal flat in the Wadden Sea. Mar Ecol Prog Ser 111:251-257

Rasmussen E (1977) The wasting disease of eelgrass (Zostera marina) and its effects on environmental factors and fauna. In: McRoy CP, Helfferich C (eds) Seagrass ecosystems: a scientific perspective. Marcel Dekker, New York, p 1-52

Reid RN, MacKenzie CL Jr, Vitaliano JJ (1993) A failed attempt to re-establish eelgrass in Raritan Bay (New York/New Jersey). Northeast Fisheries Science Center Reference Document 93-27. NOAA/National Marine Fisheries Service, Highland, NJ

Short FT (1987) Effects of sediment nutrients on seagrasses, literature review and mesocosm experiment. Aquat Bot $27: 41-57$

Short FT (1988) Eelgrass-scallop research in the Niantic River. Waterford-East Lyme, Connecticut Shellfish Commission, Final Report. Jackson Estuarine Laboratory, Durham, NH

Short FT (1993) The Port of New Hampshire Interim Mitigation Success Assessment Report. Report to the New Hampshire Department of Transportation. Jackson Estuarine Laboratory, Durham, NH

Short FT, Burdick DM (1996) Quantifying eelgrass habitat loss in relation to housing development and nitrogen loading in Waquoit Bay, Massachusetts. Estuaries 19:730-739

Short FT, Neckles H (1999) The effects of global climate change on seagrasses Aquat Bot 63:169-196

Short FT, Wyllie-Echeverria S (1996) Natural and humaninduced disturbance of seagrasses. Environ Conserv 23: $17-27$

Short FT, Mathieson AC, Nelson JI (1986) Recurrence of the eelgrass wasting disease at the border of New Hampshire and Maine, USA. Mar Ecol Prog Ser 29:89-92

Short FT, Burdick D, Wolf J, Jones GE (1993) Eelgrass in estu-

Editorial responsibility: Kenneth Heck (Contributing Editor), Dauphin Island, Alabama, USA arine research reserves along the East Coast, USA. Part I: declines from pollution and disease and Part II: Management of eelgrass meadows. NOAA, Coastal Ocean Program Publ, Durham, NH

Short FT, Burdick DM, Kaldy JE (1995) Mesocosm experiments quantify the effects of eutrophication on eelgrass, Zostera marina L. Limnol Oceanogr 40:740-749

Short FT, Burdick DM, Bosworth W, Grizzle RE, Davis RC (1998) New Hampshire Port Authority Mitigation Project Progress Report, June 1998. Prepared for the New Hampshire Port Authority and the New Hampshire Department of Transportation. Jackson Estuarine Laboratory, Durham, $\mathrm{NH}$

Short FT, Kopp BS, Davis RC (1999) Transplanting eelgrass (Zostera marina) with remote frames: a low-cost, effective habitat restoration method. 15th Biennial International Conference. Estuarine Research Federation, New Orleans

Short FT, Burdick DM, Short CA, Davis RC, Morgan PA (2000) Developing success criteria for restored eelgrass, salt marsh and mud flat habitats. Ecol Eng 15:239-252

Short FT, Kopp BS, Gaeckle J, Tamaki H (2002) Seagrass ecology and estuarine mitigation: a lowcost method for eelgrass restoration. Fish Sci (in press)

Stevenson JC, Staver LW, Staver KW (1993) Water quality associated with survival of submersed aquatic vegetation along an estuarine gradient. Estuaries 1:346-361

Suchanek TH (1983) Control of seagrass communities and sediment distribution by Callianassa (Crustacea, Thalassidnidea) bioturbation. J Mar Res 41:281-298

Thayer GW, Kenworthy WJ, Fonseca MS (1984) The ecology of eelgrass meadows of the Atlantic coast: a community profile. US Fish and Wildlife Service, Slidell, LA (FWS/OBS-84/24)

Thom RM (1990) A review of eelgrass (Zostera marina L.) transplanting projects in the Pacific Northwest. Northwest Environ J 6:121-137

Valiela I, Foreman K, LaMontagne M (1992) Couplings of watersheds and coastal waters: sources and consequences of nutrient enrichment in Waquoit Bay, Massachusetts. Estuaries 15:443-457

Vanasse Hangen Brustlin Inc. (1996) New Bedford Harbor: historic overview, natural resources, uses status report. New Bedford Harbor Trustee Council, Gloucester, MA

Zimmerman RC, Reguzzoni JL, Wyllie-Echeverria S, Josselyn M, Alberte RS (1991) Assessment of suitability for growth of Zostera marina L. (eelgrass) in San Francisco Bay. Aquat Bot 39:353-366

Zimmerman RC, Reguzzoni JL, Alberte RS (1995) Eelgrass (Zostera marina L.) transplants in San Francisco Bay: role of light availability on metabolism, growth and survival. Aquat Bot 51:67-86

Submitted: March 7, 2000, Accepted: May 14, 2001

Proofs received from author(s): February 4, 2002 